\title{
SOME NEW SUPRA-LITTORAL PROTISTA
}

\author{
By M. R. Droop \\ The Marine Station, Millport
}

(Text-figs. I-I9)

This communication is devoted to furnishing diagnoses of six organisms recently isolated from supra-littoral rock pools on the island of Cumbrae. Much of their interest derives from their being available in bacteria-free cultures; on the other hand, with one exception, all are frequent and typical members of the brackish supra-littoral.

Accounts of habitats in many ways similar to those on Cumbrae are to be found in Bohlin (I897), Levander (I900), Carter (I937), Conrad (I939) and Droop (1953). According to Bohlin's classification the pools may be divided broadly into three categories: (I) 'brackish', rock pools in which the influence of sea splash is dominant; (2) 'rain', rock pools beyond the normal reach of splash but not influenced by land drainage; (3) 'peat', pools with coloured water receiving drainage from surrounding peaty soil. On Cumbrae pools are found both on the friable Devonian rock and the hard basalt dykes. 'Rain' pools are not plentiful, probably from absence of any agency keeping the rocks beyond the immediate range of sea splash free from phanerogamic vegetation. Where they do occur they usually contain Haematococcus pluvialis. The 'brackish' pools are mostly under Io 1 . in capacity and are subject to extreme fluctuations in salinity and alkalinity and dry up frequently. Typical dominants other than the species to be described are Oxyrrhis marina, Monochrysis lutheri, Chlamydomonas pulsatilla and Platymonas spp. The 'peat' pools, though mostly fresh, are subject to occasional inundations by the sea. Their reaction is normally neutral, as they do not support heavy populations.

\section{Cultivation}

A modification of Pringsheim's (I946) technique was employed for making isolations (Droop, I954a). Cultures were at first maintained in a complex medium such as medium I below, but later it became possible in a number of cases to substitute for this completely 'synthetic' solutions, of which $S_{20}$ and $S 22$ are examples. 


\section{Medium I}

\begin{tabular}{|c|c|c|c|}
\hline Soil extract & $20 \mathrm{mg}^{1}$ & $\mathrm{~K}_{2} \mathrm{HPO}_{4}$ & IO $\mathrm{mg}$ \\
\hline Liver extract ('Oxoid' & $100 \mathrm{mg}$ & Natural sea water & $1000 \mathrm{ml}$. \\
\hline $\begin{array}{l}\text { Tryptone peptone } \\
\text { ('Difco') }\end{array}$ & $100 \mathrm{mg}$ & $\begin{array}{l}\text { diluted to appropriate } \\
\text { strength with glass- }\end{array}$ & \\
\hline $\mathrm{KNO}_{3}$ & . $100 \mathrm{mg}$ & $\begin{array}{l}\text { distilled water and } \\
\text { autoclaved separately } \\
\text { from the nutrients }\end{array}$ & \\
\hline
\end{tabular}

\begin{tabular}{|c|c|c|c|}
\hline \multicolumn{2}{|l|}{$\mathrm{S}_{20}$} & \multicolumn{2}{|c|}{$S_{22}$} \\
\hline $\mathrm{KNO}_{3}$ & IOO mg & Glycine & $40 \mathrm{mg}$ \\
\hline $\mathrm{K}_{2} \mathrm{HPO}_{4}$ & Io $\mathrm{mg}$ & Guanine & $40 \mathrm{mg}$ \\
\hline 'S.W. I' & $250 \mathrm{ml}$ & Uric acid & $4 \mathrm{mg}$ \\
\hline 'S.W. 2' & $5 \mathrm{ml}$. & Thiamin & I $\mathrm{mg}$ \\
\hline 'T.M. 2' & IO $\mathrm{ml}$. & Cobalamin & IOO $\mathrm{m} \mu \mathrm{g}$ \\
\hline Glass-distilled water & $730 \mathrm{ml}$ & Medium $S_{20}$ & $1000 \mathrm{ml}$. \\
\hline
\end{tabular}

\begin{tabular}{|c|c|c|c|}
\hline \multicolumn{2}{|l|}{ 'S.W.I' } & \multicolumn{2}{|c|}{ 'S.W. 2 ' } \\
\hline $\mathrm{NaCl}$ & $60 \mathrm{~g}$ & $\mathrm{SrCl}_{2}$ & $1000 \mathrm{mg}$ \\
\hline $\mathrm{MgCl}_{2} \cdot 6 \mathrm{H}_{2} \mathrm{O}$ & IO $\mathrm{g}$ & $\mathrm{KBr}$ & $3000 \mathrm{mg}$ \\
\hline $\mathrm{KCl}$ & $\mathrm{I} \cdot 5 \mathrm{~g}$ & $\mathrm{Al}_{2}\left(\mathrm{SO}_{4}\right)_{3}$ & $50 \mathrm{r}$ \\
\hline $\mathrm{CaSO}_{4}$ & $2 \mathrm{~g}$ & $\mathrm{LiCl} . \mathrm{H}_{2} \mathrm{O}$ & Io 1 \\
\hline Glass-distilled water to & $1000 \mathrm{ml}$. & $\mathrm{RbCl}$ & Io $\mathrm{n}$ \\
\hline & & Glass-distilled water & 1000 \\
\hline
\end{tabular}

$\begin{array}{lrlr}\text { EDTA }^{2} & 2000 \mathrm{mg} & \mathrm{NaMoO}_{4} & 40 \mathrm{mg} \\ \mathrm{Fe}-\mathrm{CDTA} & 70 \mathrm{mg} & \mathrm{CoSO}_{4} & \mathrm{I} \cdot 7 \mathrm{mg} \\ \mathrm{ZnSO}_{4} & 560 \mathrm{mg} & \mathrm{CuSO}_{4} & 0.3 \mathrm{mg} \\ \mathrm{MnSO}_{4} & 200 \mathrm{mg} & \mathrm{Glass}_{4} \text { distilled water } & 1000 \mathrm{ml} .\end{array}$

${ }^{1} 4 \mathrm{ml}$. of an extract of soil which yielded $5 \mathrm{~g}$ dry wt. of humic substance per 1 . on acidification.

${ }^{2}$ Disodium ethylene diamine tetra-acetate.

$S_{20}$ is a 'synthetic' substitute for enriched half strength sea water (cf. Hutner \& Provasoli, I95I; Provasoli \& Pintner, I953). Although possibly needlessly complex, it may be quickly prepared from the stock solutions. It has formed the core of several successful solutions for 'marine' organisms. $S_{22}$ is suitable for Prymnesium parvum and Monochrysis lutheri and the Syracosphaera and Hemiselmis described below. The function of the organic ingredients glycine, guanine and uric acid is not at present clear; all appear to be necessary. It is possible that they serve to increase the buffer capacity of the medium in the alkaline region. The growth factors represented may be superfluous in some instances, but a quantitative dose-response relation has been established for the four species mentioned with cobalamin (Droop, I954b), and this 
vitamin is probably needed by other Chrysophyceae. $\mathrm{pH}$ of the medium should be adjusted with $\mathrm{Na}_{2} \mathrm{CO}_{3}$ to about 8 for most supra-littoral species. Media below $\mathrm{pH}_{7}$ are toxic and above $\mathrm{pH} 9$ they tend to precipitate unless autoclaving is reduced to an absolute minimum.

\section{CHLOROPHYCEAE}

\section{Chlorococcales}

Nannochloris oculata n.sp. (Figs. I-6) (Strain no. 66) ${ }^{1}$

Cellulae globosae 2-4 $\mu$ diam., aut solitariae aut aggregatae; chromatophoro singulo, pallido viridi, parietino per parte peripheriam cellulae occupanti; stigmate pallido rubro, rotundo, ad chromatophorum locato; sine pyrenoide, sed I-3 granis magnis amylaceis parietinis praeditae; tegumento delicatissimo persistanti, sed circum cellulas juvenes inviso et vix maturas apparenti. Propagatur per fissionem pariens cellulas filias duas (non autosporas). Cellulae filiae aut liberes aut ad liminem tegumenti materni dirupti manentes.

Cells globose $2-4 \mu$ diam. solitary or aggregated; chromatophore single, pale green, parietal occupying but a portion of the circumference; stigma pale orange-red, circular, associated with the chromatophore; pyrenoid lacking; starch grains I-3, conspicuous, parietal; cell-wall very delicate, invisible in young cells, becoming plainer just before division. Cell division into two daughter cells (not autospores). Daughter cells free or remaining at the mouth of the split maternal tegument.

The genus Nannochloris Naumann (I93I) is taken by Butcher (I952) to include minute Chlorella-like organisms without visible cell-wall in which cell-division resulted in two daughter cells. In Nannochloris oculata the presence of a delicate external membrane at certain stages of the life cycle casts some doubt on the true affinities of the species. However, since this character varies in its expression, being quite undetectable under some conditions, and at no time sufficiently firm to modify the mode of cell-division characteristic of Nannochloris, it was thought most expedient to place the species there. $N$. oculata differs from other described species also in the possession of a pale circular stigma.

The cell-wall is never visible in young cells, which always appear naked. It is seen first in mature cells just before division, when it has the appearance of a faintly granular investment. As division proceeds this investment enlarges so that space is visible between it and the cell. After division, daughter cells are freed by splitting of the investment, but one or both may remain attached to it, leading in extreme cases to a loose subdendroid colony reminiscent of

\footnotetext{
1 Strain numbers refer to Millport cultures.
} 
Dichotomococcus capitatus Korschikof (1928). The investment stains well with I \% cresyl blue, when the granulation is very marked. At no time does it appear gelatinous. The environmental conditions leading to its greatest expression are not yet clear to me but I have the impression that they are concomitant with optimum conditions for growth. Colony formation is encountered in the field as well as in cultures.

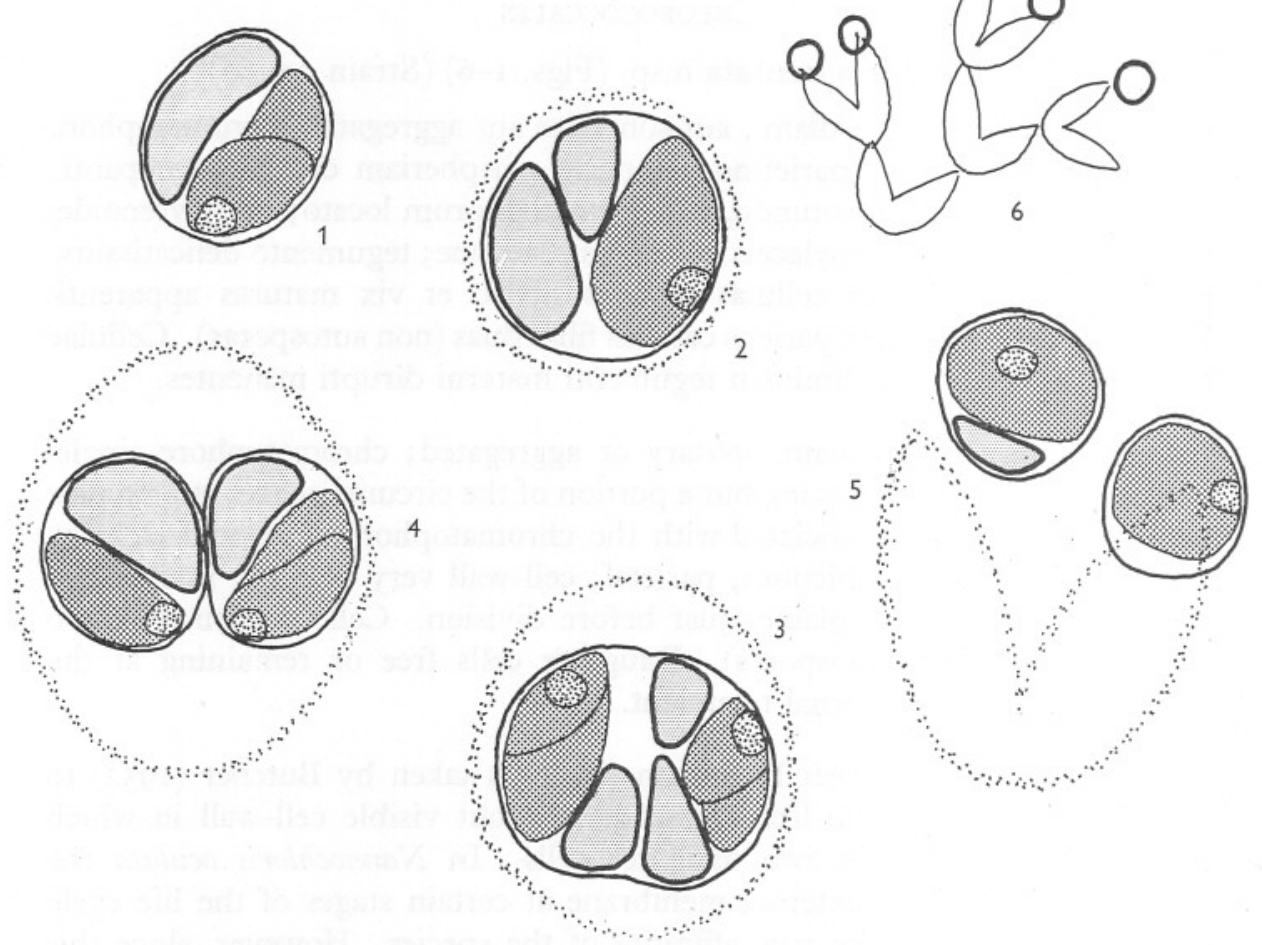

Figs. I-6. Nannochloris oculata n.sp. Figs. I-5, stages in cell division, $\times 7,500$.

Fig. 6, 'Colony' formation, $\times 1,750$.

The protoplast of Nannochloris oculata is clear and structureless and has no visible inclusions other than those mentioned. The chromatophore is pale at all times, but in actively growing cultures is dark enough to make the stigma hard to observe. In nitrogen-deficient cultures, however, it becomes very pale indeed and the stigma is then quite plain. The change in the relative intensity of stigma and chromatophore is reflected in the naked-eye aspect of cultures which turn from yellow-green to brown as if there were carotenoids accumulating.

$N$. oculata is a frequent inhabitant of brackish rock pools on Cumbrae, particularly those of low salinity on the basalt. Ten out of II 5 pools examined 
in the summer of 1953 contained $N$. oculata as a dominant. Table I shows salinity analysis of these records, including data of the eight species most frequently encountered.

A pure clone (no. 66) of $N$. oculata was obtained by plating a suitable dilution of a sample on I \% agar with $50 \mathrm{mg} / 1$. soil extract prepared with $50 \%$ natural sea water. Growth was quite good in soil-extract agar but liquid media

\section{Table I. Salinity Distribution of Some Field Records}

(Entries refer to number of records.)

Species

Haematococcus pluvialis

Chlamydomonas pulsatilla

Nannochloris oculata

Euglena proxima

Hemiselmis virescens

Brachiomonas submarina

Platymonas spp.

Syracosphaera elongata

Monochrysis lutheri

Oxyrrhis marina

Total salinity records

\begin{tabular}{|c|c|c|c|c|c|}
\hline \multicolumn{5}{|c|}{ Salinity $(\% \circ)$} & \multirow{2}{*}{$\begin{array}{l}\text { Total } \\
\text { species } \\
\text { records }\end{array}$} \\
\hline 0 to 0.4 & 0.4 to $I \cdot 6$ & $I \cdot 6$ to $6 \cdot 4$ & 6.4 to 25 & Above 25 & \\
\hline 7 & I & . & . & . & 8 \\
\hline I & 3 & 3 & . & . & 7 \\
\hline I & 3 & -3 & 2 & I & IO \\
\hline 2 & 2 & 4 & 3 & . & I I \\
\hline$\dot{z}$ & 2 & 5 & 4 & I & I2 \\
\hline 5 & 7 & I5 & 5 & 3 & 35 \\
\hline I & 2 & I & 8 & 4 & I6 \\
\hline . & I & I & 2 & 2 & 6 \\
\hline . & 3 & 5 & 7 & 4 & I9 \\
\hline$\cdot$ & - & 7 & I4 & IO & $3 I$ \\
\hline I2 & 22 & 32 & 23 & I7 & - \\
\hline
\end{tabular}

TABLE II. Utilization of SOME N Compounds IN the Presence of Soll Extract

(+, efficient; ?, doubtful; o, not utilized; -, compound harmful.)

Haematococcus pluvialis

Nannochloris oculata

Monochrysis lutheri

Syracosphaera elongata

Prymnesium parvum
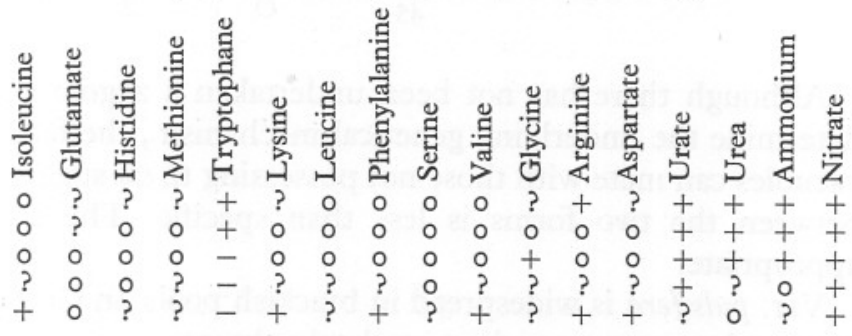

were improved by casein digest or any of a number of carboxylic acids, purines, and nucleotides, particularly if $\mathrm{pH}$ of the medium was on the low side. Medium $S_{20}, \mathrm{pH}$ at least 7.5 is satisfactory, but it is more reliable with the addition of $40 \mathrm{mg} / \mathrm{l}$. glutamic acid. $N$. oculata is an obligate phototroph and is non-auxotrophic. It is able to use as $\mathrm{N}$ sources nitrate, ammonium, urea, uric acid, and the amino-acid tryptophane. Glutamic acid is also utilized, but very inefficiently (Table II). Tolerance of a wide salinity range in the field indicated in Table I is matched by its performance in cultures in which relative growth rate was found to be maximal (a daily twofold increase with $200 \mathrm{ft}$ candles warm white fluorescent light for $\mathrm{I} 6 \mathrm{~h}$ each day) in salinities between 4 and $36 \%$, and cultures could be maintained in salinities between 2 and $54 \%$. 


\section{VOLVOCALES}

Brachiomonas submarina var. pulsifera n.var. (Strains nos. 44 and 45 )

Monada speciei Brachiomonas submarina Bohlin em. Droop, antice quatuor vacuolis contractilibus praedita.

Cells with the characters of Brachiomonas submarina Bohlin em. Droop, but provided with four anterior contractile vacuoles.

B. submarina is a sexual organism with, apparently, two mating types (Droop, I953); var. pulsifera is no exception. Originally twenty-five clones of individuals possessing four contractile vacuoles were isolated, nine of which were of one mating type and 16 of the other. One of each type was retained in culture (strains nos. 44 and 45 ), and proved to be compatible with one or other of the existing strains of $B$. submarina var. submarina (strains nos. 42 and 43 ). Table III shows the pattern of compatibility.

TABLE III. Compatibility In BRACHIOMONAS

(Z, compatible; $\mathrm{O}$, incompatible.)

\begin{tabular}{lccccc} 
& & \multicolumn{4}{c}{} \\
\cline { 3 - 5 } & Strain & 42 & 43 & 44 & 45 \\
Var. submarina & 42 & $\mathrm{O}$ & $\mathrm{Z}$ & $\mathrm{Z}$ & $\mathrm{O}$ \\
& 43 & $\mathrm{Z}$ & $\mathrm{O}$ & $\mathrm{O}$ & $\mathrm{Z}$ \\
Var. pulsifera & 44 & $\mathrm{Z}$ & $\mathrm{O}$ & $\mathrm{O}$ & $\mathrm{Z}$ \\
& 45 & $\mathrm{O}$ & $\mathrm{Z}$ & $\mathrm{Z}$ & $\mathrm{O}$
\end{tabular}

Although there has not been undertaken a zygote analysis, which would determine the underlying genetical mechanism, the fact that cells possessing vacuoles can mate with those not possessing them suggests that the difference between the two forms is less than specific. The status Variety seemed appropriate.

Var. pulsifera is widespread in brackish pools on Cumbrae. Curiously, the type variety appears to be completely absent.

\section{CRYPTOPHYCEAE \\ NEPHROSELMIDACEAE}

Hemiselmis virescens n.sp. (Figs. 7-II) (Strain no. 64)

Monada generis Hemiselmis Parke chromatophore laete viride.

Having examined a culture of $H$. rufescens ('Flagellate D' (Parke, 1949)) kindly supplied by Dr Parke, I have been unable to detect any difference between the present species and $H$. rufescens other than colour of the chromatophore. In healthy cultures of $H$. virescens the latter is an almost brilliant 
green, so that to the naked eye cultures appear pale turquoise to bottle-green according to their density. Figs. 7-II, however, differ from Dr Parke's of $H$. rufescens in the following points: length and stiffness of the flagella, flagellar insertion, number and position of stigmata, and orientation of the two rows of trichocysts. The number and position of the stigmata vary in both species and should in all probability be related to the health of the material. The other differences are, in my opinion, differences in interpretation of small structures. Cells of $H$. virescens are mostly between 5 and $7 \mu$ in length.

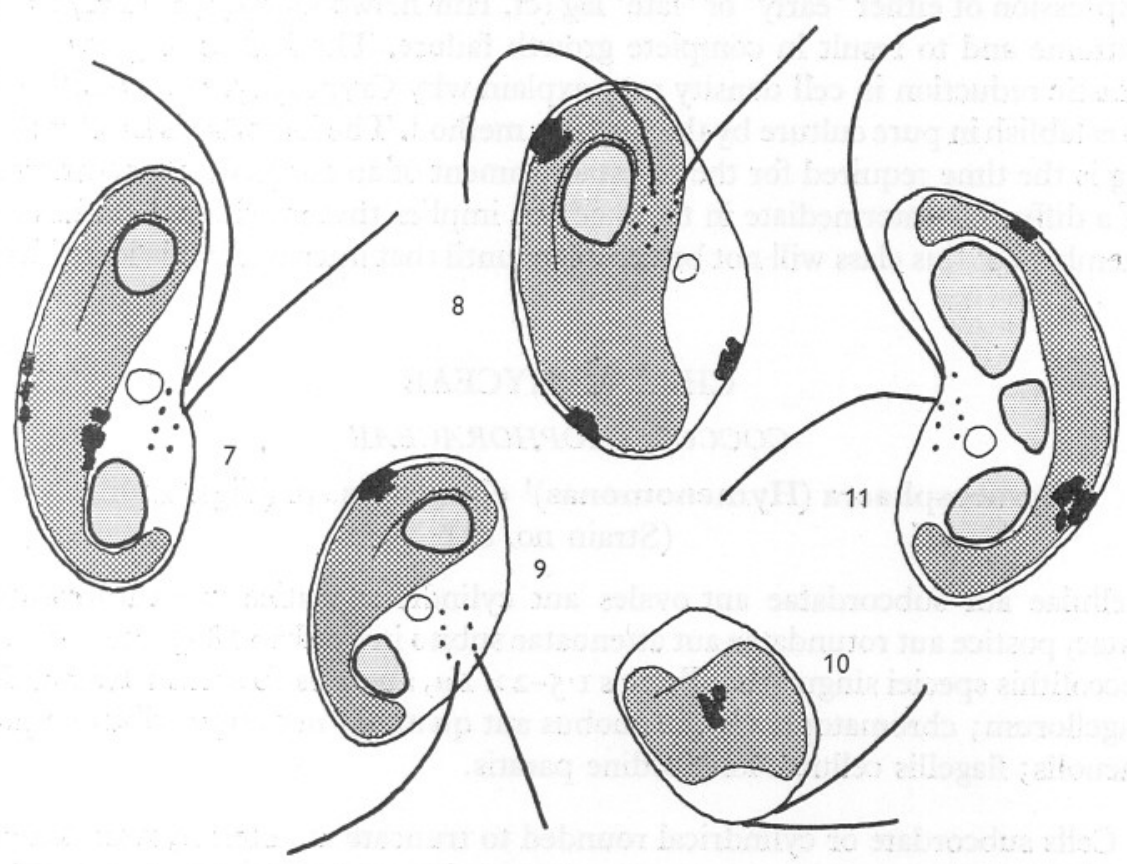

Figs. 7-II. Hemiselmis virescens n.sp., $\times 5,000$.

H. virescens is widely distributed in supra-littoral pools on Cumbrae; its appearance is rather spasmodic, but on occasions it is to be found in enormous numbers (c. 30 million per ml.). Pools of low salinity are favoured but it has a great range (Table I). It is also recorded from Öregrund, Sweden.

The type strain (no. 64) was isolated in July 1953 from a very small pool on Skate Point. The difficulties encountered in isolation of this strain are matched by those of its maintenance. Paradoxically, it has proved easier to maintain in the synthetic medium $S_{22}$ than in any variant of the original isolation medium containing soil and liver extracts. Nutritional requirements are not fully worked out; that room exists for improvement in the medium is shown both by the high yields in nature which cannot yet be achieved in the laboratory and by the improvement frequently obtained in two-member 
cultures, e.g. cultivated with another flagellate such as Monochrysis lutheri. In that case, incidentally, growth of $M$. lutheri is largely suppressed.

The only vitamin requirement of Hemiselmis virescens thus far definitely identified is one for cobalamin.

Successful maintenance of this species depends both upon sufficient material $(0.2 \mathrm{ml}$. per $5 \mathrm{ml}$.) being transferred on subculturing and on cultures not being allowed to age. Subculturing should be carried out fortnightly. Apparently enzymatic changes occur so quickly in cells not actively multiplying that any expression of either 'early' or 'late' lag (cf. Hinshelwood, I946) is likely to be extreme and to result in complete growth failure. The failure to grow after drastic reduction in cell density may explain why Cryptophyceae are difficult to establish in pure culture by the washing method. The hypothesis that 'early' lag is the time required for the re-establishment of an adequate concentration of a diffusible intermediate in the medium implies that nutritional studies on members of this class will not be complete until that intermediate is identified.

\section{CHRYSOPHYCEAE \\ COCCOLITHOPHORACEAE}

Syracosphaera (Hymenomonas) ${ }^{1}$ elongata n.sp. (Figs. I2-I4)

(Strain no. 62)

Cellulae aut subcordatae aut ovales aut cylindricae antice truncato-rotundatae, postice aut rotundatae aut attenuatae subito in caudam I8-30 $\times \mathrm{I} 2-\mathrm{I} 5 \mu$; coccolithis speciei singularis ellipticis $\mathrm{I} \cdot 5-2 \times \mathrm{I} \mu$, absentis ab area instructantis flagellorum; chromatophoris aut duobus aut quatuor; nec stigmatibus neque vacuolis; flagellis cellulae longitudine paratis.

Cells subcordate or cylindrical rounded to truncate at anterior, rounded or suddenly attenuated to a short point at posterior I8-30 $\times \mathrm{I} 2-\mathrm{I} 5 \mu$; coccoliths of a single type, oval, I.5-2 $\times \mathrm{I} \mu$, absent from area surrounding flagellar insertion; chromatophores 2 or 4 ; neither stigma nor vacuoles; flagella as long as the cell, not longer. Euryhaline.

$S$. elongata most nearly resembles S. carterae $^{2}$ Braarud \& Fagerland (I946) particularly as to size, shape and structure of coccoliths. I am indebted to Prof. T. Braarud for electron-microscope observations on the coccoliths of my strain.

The points of difference between $S$. elongata and $S$. carterae which warrant the creation of a new species are size and shape of the cell and length of flagella. S. elongata is $\mathrm{I} \frac{1}{2}$ times the size of $S$. carterae and the cell length/breadth ratio tends on the whole to be much greater. A ratio of $2-4$ is usual. The

1 Nomenclature under review (T. Braarud, personal communication.)

${ }^{2}$ Living material of both the Blindern and Plymouth strains has been examined. 
flagella, on the other hand, are relatively shorter than those of $S$. carterae, being rarely longer and frequently shorter than the cell length. On account of this, $S$. elongata moves noticeably more sluggishly than does $S$. carterae. There is no doubt, however, that the two species are closely related.

$S$. elongata is a moderately frequent inhabitant of brackish pools of rather high salinity on Cumbrae. Sometimes it occurs in great numbers, though more usually few individuals are encountered.
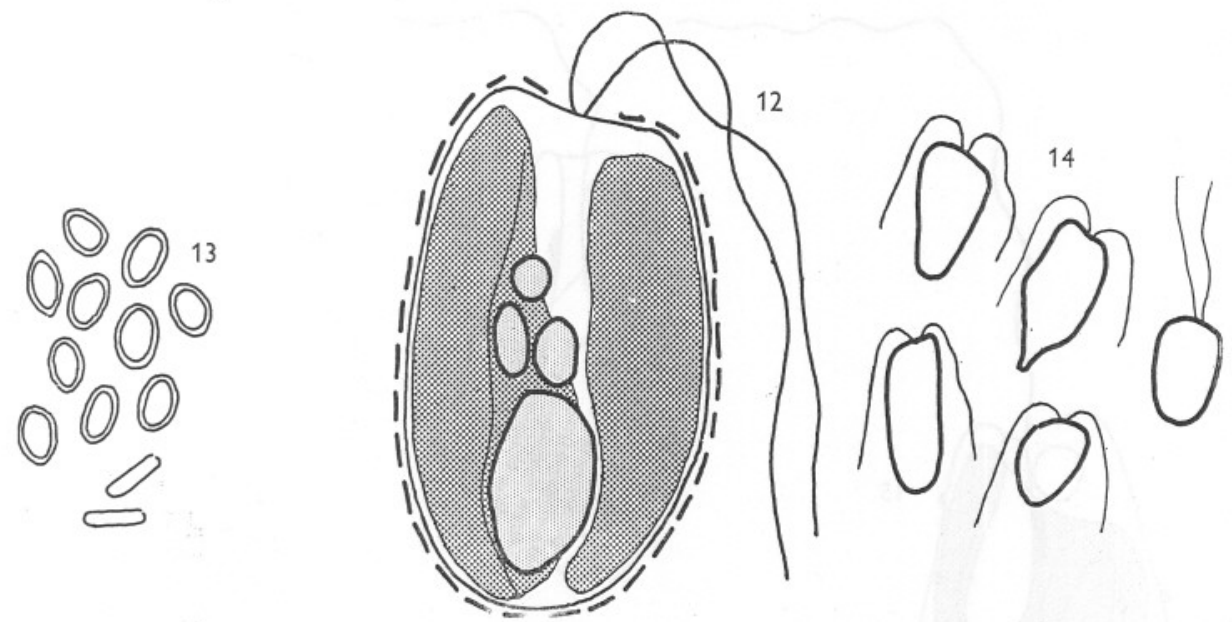

Figs. I2-I4. Syracosphaera elongata n.sp. Fig. I2, typical cell in culture, $\times 2,500$.

Fig. I3, coccoliths, $\times 3,500$. Fig. I4, cells from wild material, $\times 500$.

A clone of this species has been maintained for a year in medium $S 22$, but has also been cultured in media with salinity as low as 8 and as high as $90 \%$. There is an absolute requirement for cobalamin and, in certain circumstances, thiamin has a stimulating effect; no other growth requirements have been identified. It appears to be an obligate phototroph, as none of a large range of organic carbon compounds support growth in the dark. Nitrate and uric acid are good sources of nitrogen for this species while ammonium, urea and amino acids are utilized not at all or with difficulty (Table II).

\section{MALLOMONADACEAE}

Microglena arenicola n.sp. (Figs. I5-I7) (Strain no. 72)

Monada submarina generis Microglena Ehrenberg, cylindricato-ovata, paulum asymmetrica et compressa, antice oblique truncato-rotundata depressione vadosa instructa ad oram ampullae, postice aut rotundata aut attenuata subito in caudam, $\mathrm{I} 2-\mathrm{I} 6 \mu$ longae, 8-II $\mu$ crassae; periplasto delicatissimo, antice paucis, postice pluris, siliculis minutis praedito; flagello ad oram ampullae inserto, longiore paulum longitudine cellulae, clinato antice; vacuolo con- 
tractili singulo, in ampullam fundenti; chromatophoro singulo aut poculiformi aut sinuato, ventum ampullae circumdato; stigmate magno, laete rubro, ad collum ampullae locato; nucleo postice, sed ante leucosini guttam locato.

Cells cylindrical to ovate slightly compressed and asymmetrical, anteriorly obliquely truncate to rounded with a small shallow depression leading to the reservoir mouth, posteriorly rounded or attenuated suddenly to a point;

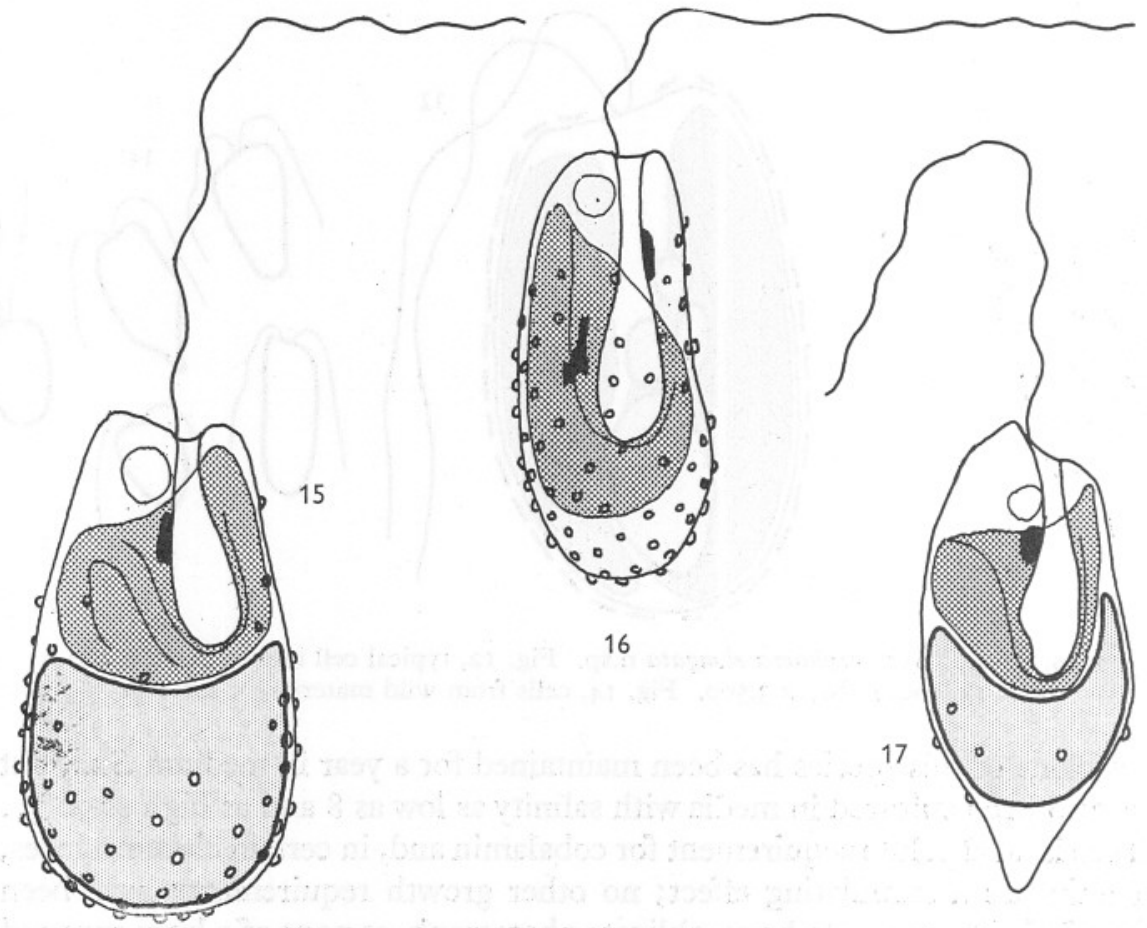

Figs. 15-17. Microglena arenicola n.sp., $\times$ 5,000.

I2-I6 $\times 8-\operatorname{II} \mu$; periplast thin with small silicious punctae, mostly at rear; flagellum arising at reservoir mouth, slightly longer than cell, anterior tip inclined sharply during forward movement; contractile vacuole single, emptying into the reservoir; chromatophore single, embracing reservoir belly, cup shaped or folded to an S; stigma large, bright red, at reservoir neck; nucleus lying between chromatophore and posterior leucosin body. Euryhaline.

$M$. arenicola is similar in shape to $M$. punctifera Ehr., particularly as regards the anterior indention but it is much smaller and relatively narrower anteriorly. Figs. I5 and I6 show typical specimens, while Fig. I7 shows one with the posterior point, possibly associated with exudation of leucosin. The vacuolar apparatus differs from that of other species (cf. Conrad, I927) in that there is but a single contractile vacuole. 
During March and April 1954 high seas had left on the sand of Kames Bay, Millport, a large quantity of brown weed which had become partly buried and rotten. The result was a fine bloom of flagellates and algae on the sand where there was freshwater seepage. Dark green patches were mostly Euglena proxima; light green or yellow patches, Microglena arenicola. Salinity of the water containing the flagellates was less than $4 \%$.

No difficulty was encountered in isolating $M$. arenicola, but satisfactory maintenance media await development. At present it is maintained in $S_{22}$ with or without the addition of silica. It is extremely phototactic in cultures.

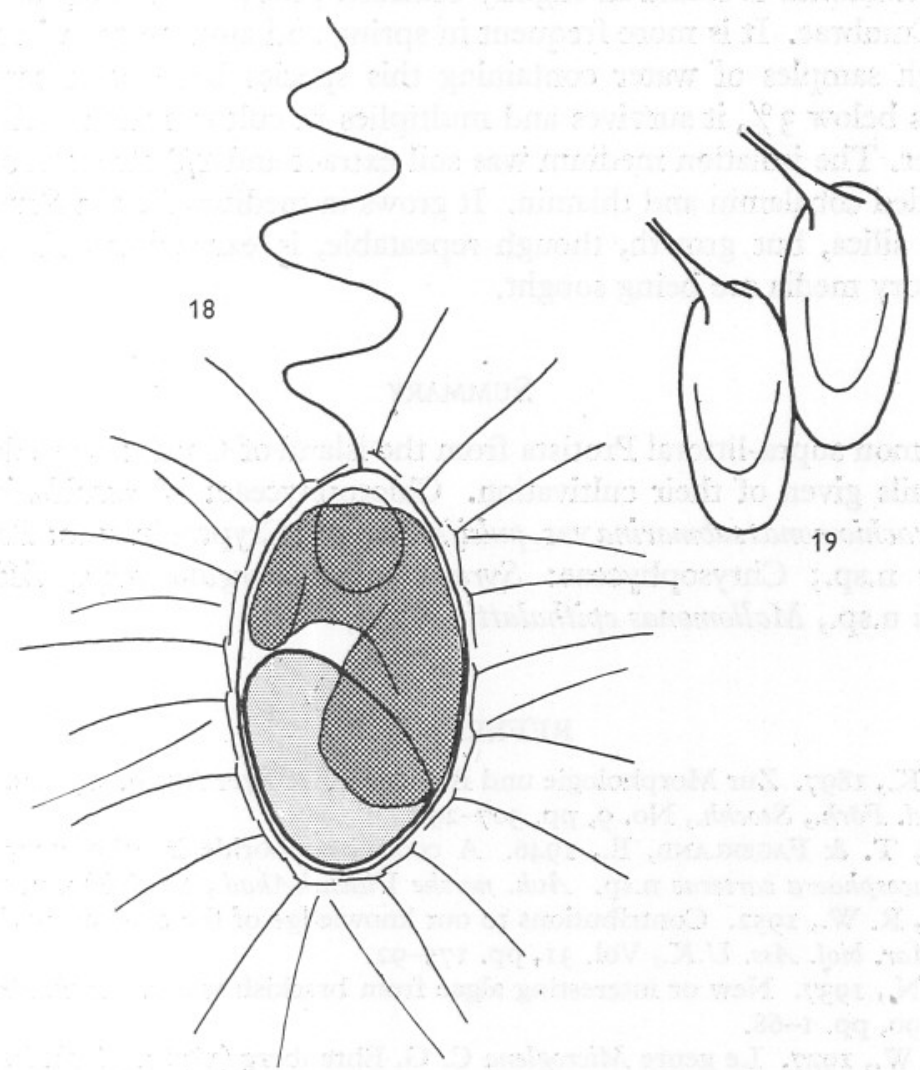

Figs. 18, 19. Mallomonas epithalattia n.sp. Fig. I8, typical cell, $\times 1,500$. Fig. 19, two plates, $\times 8,000$

Mallomonas epithalattia n.sp. (Figs. I8, I9) (Strain no. 7I)

Cellulae ovatae vel ellipsoideae $20-30 \times \mathrm{IO}-\mathrm{I} 5 \mu$; scutis ellipticis $4 \times \mathrm{I} \cdot 5 \mu$, setis simplicibus aequaliter dispersis et radiantibus IO-I $5 \mu$ longis; chromatophoro singulo parietino; nucleo antice. 
Cells ovoid to ellipsoid $20-30 \times$ IO-I $5 \mu$ with elliptical plates $4 \times \mathrm{I} \cdot 5 \mu$ and setae evenly distributed and radially divergent, IO-I $5 \mu$ long, entire; with single parietal chromatophore and anterior nucleus.

Neither reservoir, contractile vacuoles nor cysts have been observed in M. epithalattia. This species differs from others with oval plates in having but a single chromatophore (Conrad, 1933). Except for the shape of the plates, there is a strong resemblance to $M$. fresenii Kent. The plates of $M$. epithalattia are very delicate and are nearly invisible unstained, but they take up aqueous cresyl blue satisfactorily.

M. epithalattia is found in slightly brackish peat pools mainly on Farland Point, Cumbrae. It is more frequent in spring and autumn than in summer. Although samples of water containing this species have been confined to salinities below $3 \%$ it survives and multiplies in cultures with half strength sea water. The isolation medium was soil extract and $\mathrm{r} / 8$ strength sea water with added cobalamin and thiamin. It grows in medium I or in $S 22$, with or without silica, but growth, though repeatable, is exceedingly light. More satisfactory media are being sought.

\section{SUMMARY}

Six common supra-littoral Protista from the island of Cumbrae are described and details given of their cultivation. Chlorophyceae: Nannochloris oculata n.sp., Brachiomonas submarina var. pulsifera n.var.; Cryptophyceae: Hemiselmis virescens n.sp.; Chrysophyceae: Syracosphaera elongata n.sp., Microglena arenicola $\mathrm{n}$.sp., Mallomonas epithalattia $\mathrm{n} . \mathrm{sp}$.

\section{REFERENCES}

BoHLIN, K., I897. Zur Morphologie und Biologie einzelliger Algen. Öfvers. VetenskAkad. Förh., Stockh., No. 9, pp. 507-29.

BRAARUD, T. \& FAgERLAND, E., I946. A coccolithophoride in laboratory culture: Syracosphaera carterae n.sp. Avh. norske VidenskAkad., I946, No. 2, II pp.

BUTCHER, R. W., I952. Contributions to our knowledge of the smaller marine algae. F. Mar. biol. Ass. U.K., Vol. 31, pp. 175-92.

Carter, N., I937. New or interesting algae from brackish water. Arch. Protistenk., Bd. 90 , pp. I-68.

Conrad, W., I927. Le genre Microglena C. G. Ehrenberg (1838). Arch. Protistenk., Bd. 60 , pp. 415-39.

- 1933. Révision du genre Mallomonas Perty (185I) inc. Pseudomallomonas Chodat (1920). Mém Mus. Hist. nat. Belg., No. 56, 80 pp.

- 1939. Notes Protistologiques. X. Sur le schorre de Lilloo. Bull. Mus. Hist. nat. Belg., T. I5, No. 4I, I8 pp.

Droop, M. R., I953. On the ecology of flagellates from some brackish and fresh water rock-pools of Finland. Acta bot. fenn., Vol. 51, pp. I-52.

- I954 $a$. A note on the isolation of small marine algae and flagellates for pure cultures. F. Mar. biol. Ass. U.K., Vol. 33, pp. 5II-I4. 
Droop, M. R., I954b. Cobalamin requirement in Chrysophyceae. Nature, Lond., Vol. I74, p. 520 .

Hinshelwood, C. N., 1946. The Chemical Kinetics of the Bacterial Cell. Oxford: Clarendon Press.

Hutner, S. H. \& Provasoli, L., I95I. The phytoflagellates. In: Biochemistry and Physiology of Protozoa, ed. A. Lwoff. New York: Academic Press Inc.

KoRSCHIKOFF, A., I928. Notes on some new or little-known Protococcales. I. Dichotomococcus capitatus n.gen. n.sp. 2. Bernardinella bipyramidata Chodat. Arch. Protistenk., Bd. 62, pp. 416-26.

LeVANDER, K. M., I900. Zur Kenntniss des Lebens in den stehenden Kleingewässern auf den Skäreninseln. Acta Soc. Fauna Flora fenn., Vol. I8, No. 6, I07 pp.

NaUmann, E., I93I. Notizen zur Systematik der Süsswasseralgen. Arch. Bot., Vol. I6, pp. I6-18.

Parke, M., 1949. Studies on marine flagellates. F. Mar. biol. Ass. U.K., Vol. 28, pp. $256-85$.

Pringsheim, E. G., 1946. Pure Cultures of Algae. Cambridge University Press.

Provasoli, L. \& PINTNER, I. J., I953. Ecological implications of in vitro nutritional requirements of algal flagellates. Ann. N.Y. Acad. Sci., Vol. 56, pp. 839-5I. 